\title{
PROGRAMA MATEMATIS PENYELESAIAN MASALAH PROJECT CRASHING
}

\author{
Irawati dan Abdullah Shahab \\ Program Studi Magister Manajemen Teknologi ITS \\ Email : ir_ra1978@yahoo.com
}

\begin{abstract}
The determination of project accomplishment time is tedious and time consuming. This problem is aggravated in a project with a plenty of activities exhibiting intricate interdependency among activities. The determination of project completion time, in general, is done manually using methods such as CPM or PERT. In case where the project is to be completed earlier than scheduled, the determination of activities, which are capable to be crashed, entails a new problem in a project management. A mathematical model is here proposed to solve the problem in a faster and a more accurate way. The solution could be obtained easier with the advantage of having the ability to specify optimally the activities that could be compressed to complete the project in a scheduled time with a minimum cost. The model is then applied in a project of ship maintenance with a procurement of normal and crash data time and cost. The solution of the model indicates which activities, and time requirement, could be compressed in order to complete the project in a scheduled time with a minimum cost. The model could be naturally applied to various projects.
\end{abstract}

Keywords: optimization, project crashing, mathematical programming.

\section{PENDAHULUAN}

Suatu pengamatan dilakukan pada salah satu Badan Usaha Milik Negara yang bergerak di bidang jasa dan manufaktur pembuatan, perbaikan, dan pemeliharaan kapal. Perusahaan ini memiliki kapasitas produksi yang memadai sehingga mampu melayani permintaan dalam negeri maupun permintaan luar negeri. Dalam iklim persaingan bisnis yang ketat seperti saat ini, perusahaan dituntut untuk meningkatkan kualitas dengan biaya yang kompetitif dan pengiriman yang tepat waktu.

Dalam operasinya, perusahaan ini menerima order perbaikan kapal yang secara rata-rata bisa mencapai 14 buah kapal perbulan. Masing-masing perbaikan, atau proyek ini, menuntut untuk diselesaikan sesuai dengan alokasi waktu yang direncanakan. Untuk menjawab tantangan ini, perusahaan harus mampu mengalokasikan sumber-sumber daya secara tepat agar semua proyek bisa dirampungkan sesuai dengan target waktu dan biaya yang ditentukan. Langkah ini memegang peranan yang sangat menentukan keberhasilan perusahaan, mengingat keterlambatan sebuah proyek akan menyebabkan keterlambatan pada proyek-proyek yang lain yang akan menimbulkan konsekuensi yang sangat merugikan.

Metoda yang biasa digunakan dalam perencanaan, pengawasan serta pengendalian pelaksanaan proyek adalah Critical Path Methode (CPM) dan Project Evaluation and Review Technique (PERT) (Tubagus, 1995). Metoda-metoda ini, walaupun sedikit berbeda dalam masukan waktu yang digunakan, namun pada 
Sering dijumpai dalam pengelolaan proyek, bahwa waktu yang dialokasikan untuk menyelesaikan proyek ternyata tidak sesuai dengan batas waktu yang ditentukan, sehingga diperlukan percepatan waktu total penyelesaian proyek. Durasi proyek dapat dipercepat dengan penambahan tenaga kerja (sering kali dalam bentuk lembur) dan penambahan sumber daya (material, peralatan dan lain-lain) (Ubud, 2003). Penambahan tenaga kerja dan sumber daya ini, dengan sendirinya, akan meningkatkan biaya proyek secara keseluruhan. Oleh karena itu, pengurangan waktu penyelesaian proyek harus didasarkan pada analisis biaya dan waktu. Metoda pengurangan waktu penyelesaian proyek dengan memperhitungkan biaya ini disebut Project Crashing Method yang pada prinsipnya adalah percepatan durasi proyek dengan mempercepat waktu satu atau lebih kegiatan kritis dengan biaya yang serendah mungkin.

Percepatan pelaksanaan proyek ini, dalam aplikasinya, biasanya dilakukan dengan cara mencari secara perhitungan manual lintasan kritis di dalam proyek, baik dengan menggunakan CPM atau PERT, kemudian mengurangi waktu kegiatan pada lintasan kritis yang memiliki biaya percepatan yang paling murah (Santoso, 1997). Pengurangan waktu ini harus dilakukan secara hati-hati, karena adanya kemungkinan lintasan kritis pindah ke lintasan yang lain. Mencari waktu penyelesaian proyek dengan cara mengurangi satu persatu waku kegiatan pada lintasan kritis ini bukanlah hal yang mudah, terutama ketika jumlah kegiatan di dalam proyek sangat besar.

Penelitian ini berupaya untuk menyelesaikan proses percepatan waktu proyek ini dengan menggunakan programa matematis yang bisa menyelesaikan persoalan ini tanpa harus melihat satu persatu biaya atau waktu pada lintasan kritis di dalam proyek.

\section{Permodelan Linear Programming}

Masalah percepatan proyek ini diformulasikan dalam bentuk programa matematis Linear Programming. Model linear programming ini terdiri dari satu fungsi obyektif yang akan dioptimalkan dengan beberapa kendala pembatas (Taylor, 1999). Dalam permasalahan ini, tujuan dari permodelan adalah mencari biaya yang paling rendah percepatan proyek sesuai dengan waktu yang direncanakan. Kendala yang terlibat dalam persoalan ini akan meliputi batas waktu penyelesaian proyek yang direncanakan; hubungan keterkaitan antar kegiatan dalam proyek yang tidak boleh dilanggar; dan batas waktu pemampatan kegiatan yang bisa dipercepat.

Untuk penyelesaian masalah ini dibutuhkan data yang terkait dengan waktu normal masing-masing kegiatan, biaya pemampatan waktu untuk kegiatan yang bisa dimampatkan, waktu paling rendah kegiatan yang bisa dimampatkan, dan waktu penyelesaian proyek yang direncanakan.

\section{METODOLOGI PENELITIAN}

Model matematis yang direncanakan diaplikasikan pada proyek perbaikan sebuah kapal. Data yang diperlukan untuk permodelan ini adalah waktu normal masingmasing kegiatan, biaya normal masing-masing kegiatan, waktu penyelesaian proyek yang diinginkan, dan waktu dan biaya crash masing-masing kegiatan yang bisa dimampatkan. Sebagian dari data yang dibutuhkan dalam proyek perbaikan kapal ini ditunjukkan sebagai contoh pada Tabel 1. Keterkaitan antar kegiatan ditunjukkan dalam bentuk jaringan pada Gambar 1 . 
Tabel 1. Contoh Data dan Hubungan Antar Kegiatan yang Dibutuhkan untuk Pemampatan Waktu Penyelesaian Proyek

\begin{tabular}{|c|c|c|c|c|c|c|c|c|c|}
\hline \multirow{3}{*}{ No } & \multirow{3}{*}{$\begin{array}{c}\text { Kode } \\
\text { Kegiatan }\end{array}$} & \multirow{3}{*}{ Predecessor } & \multicolumn{2}{|c|}{ Waktu Kegiatan } & \multicolumn{2}{|c|}{ Biaya Kegiatan } & \multicolumn{2}{|c|}{ Tenaga Kerja } & \multirow{3}{*}{$\begin{array}{c}\text { Crash } \\
\text { Cost/hr } \\
\text { (RP) }\end{array}$} \\
\hline & & & \multicolumn{2}{|c|}{ (Jam) } & \multicolumn{2}{|c|}{ (Rp) } & \multicolumn{2}{|c|}{ (orang) } & \\
\hline & & & Normal & Crash & Normal & Crash & Normal & Crash & \\
\hline 1 & $00-01$ & - & 1.25 & 0.5 & 4375 & 4500 & 1 & 2 & 167 \\
\hline 2 & $01-21$ & 1 & 2 & 1 & 28000 & 36000 & 4 & 8 & 8000 \\
\hline 3 & $01-02$ & 1 & 2 & 1 & 42000 & 54000 & 6 & 12 & 12000 \\
\hline 4 & $02-03$ & 3 & 2 & 1 & 7000 & 9000 & 1 & 2 & 2000 \\
\hline 5 & $03-04$ & 3,4 & 2 & 1 & 14000 & 18000 & 2 & 4 & 4000 \\
\hline 6 & $04-05$ & 5 & 1 & 0.6 & 28000 & 43200 & 8 & 16 & 38000 \\
\hline 7 & $05-06$ & 6 & 1 & 0.5 & 21000 & 25500 & 6 & 10 & 9000 \\
\hline
\end{tabular}

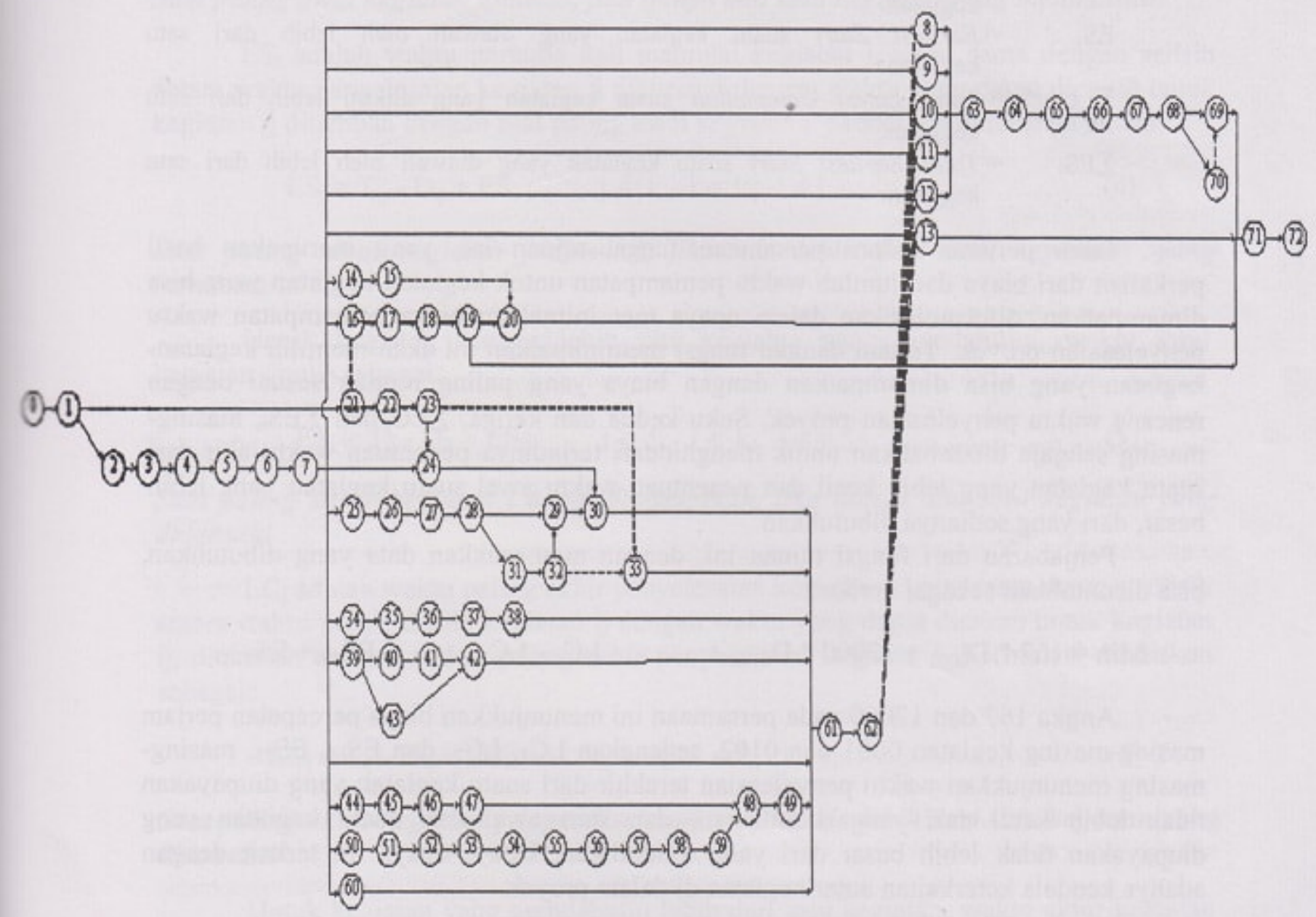

Gambar 1. Diagram Keterkaitan Antar Kegiatan pada Proses Perbaikan Kapal 


\section{PERSAMAAN MATEMATIS PROJECT CRASHING}

\section{Fungsi Tujuan}

Fungsi tujuan dari analisis Project Crashing adalah untuk meminimalkan biaya pada proses pemampatan waktu kerja dari satu atau lebih kegiatan sebatas waktu yang tersedia. Persamaan matematis untuk fungsi tujuan Project Crashing adalah:

$$
\text { Min } C=\sum_{i=1}^{n} \sum_{j \in J} \alpha_{i j} \cdot D_{i j}-\sum_{j \in J} L C_{j}+\sum_{i \in 1} E_{i}
$$

dimana:

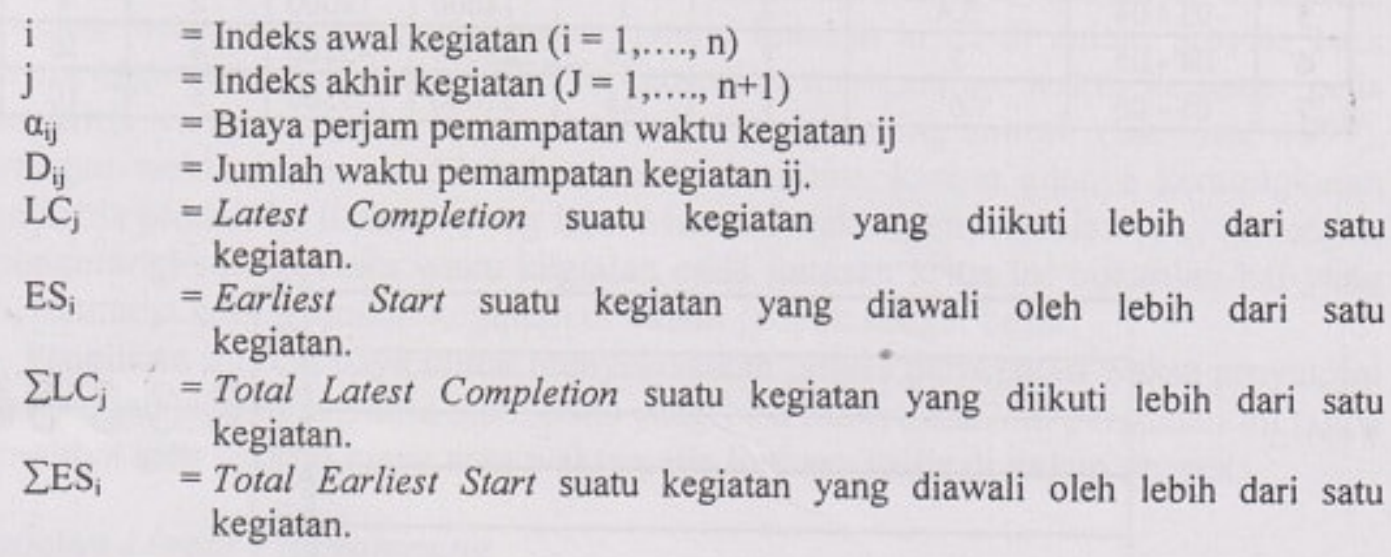

Suku pertama dalam persamaan fungsi tujuan ini, yang merupakan hasil perkalian dari biaya dan jumlah waktu pemampatan untuk kegiatan-kegiatan yang bisa dimampatkan, diformulasikan dalam upaya meminimalkan biaya pemampatan waktu penyelesaian proyek. Tujuan dengan fungsi meminimalkan ini akan memilih kegiatankegiatan yang bisa dimampatkan dengan biaya yang paling rendah sesuai dengan rencana waktu penyelesaian proyek. Suku kedua dan ketiga, $\Sigma \mathrm{LC}_{\mathrm{j}}$ dan $\Sigma E \mathrm{~S}_{\mathrm{i}}$, masingmasing sengaja ditambahkan untuk menghindari terjadinya penentuan waktu akir dari suatu kegiatan yang lebih kecil dan penentuan waktu awal suatu kegiatan yang lebih besar, dari yang sedianya dibutuhkan.

Penjabaran dari fungsi tujuan ini, dengan memasukkan data yang dibutuhkan, bisa dicontohkan sebagai berikut:

$$
\text { Min }=167 * \mathrm{D}_{0001}+12000 * \mathrm{D}_{0102}+\ldots \ldots \ldots \ldots-\mathrm{LC}_{1}-\mathrm{LC}_{7} \ldots \ldots \ldots \ldots+\mathrm{ES}_{69}+\mathrm{ES}_{71}
$$

Angka 167 dan 12000 pada persamaan ini menunjukkan biaya percepatan perjam masing-masing kegiatan 0001 dan 0102 , sedangkan $\mathrm{LC}_{1}, \mathrm{LC}_{7}$, dan $\mathrm{ES}_{69}, \mathrm{ES}_{71}$, masingmasing menunjukkan waktu penyelesaian terakhir dari suatu kegiatan yang diupayakan tidak lebih kecil dari yang dibutuhkan, dan start awal dari suatu kegiatan yang diupayakan tidak lebih besar dari yang dibutuhkan. Upaya-upaya ini terkait dengan adanya kendala keterkaitan antar kegiatan di dalam proyek. 


\section{Fungsi Pembatas}

\section{Waktu yang dibutuhkan untuk penyelesaian proyek}

Kendala batas waktu penyelesaian proyek ditentukan sesuai dengan yang diinginkan oleh perusahaan atau pemesan. Persamaan matematis kendala ini adalah:

$$
\mathrm{LC}_{\mathrm{n}+1}=\mathrm{A}
$$

Kendala ini menjamin bahwa waktu batas akhir penyelesaian kegiatan terakhir sama dengan $\mathrm{A}$, batas waktu yang direncanakan.

Saat paling awal mulainya kegiatan pertama

Kegiatan pertama proyek diawali pada hari ke 0 , sehingga dituliskan :

$$
\mathrm{ES}_{1}=0
$$

Saat paling awal kegiatan dimulai, jika hanya ada satu kegiatan yang mendahului

$\mathrm{ES}_{\mathrm{j}}$ adalah waktu pertama kali memulai kegiatan $\mathrm{j}$, yaitu sama dengan selisih antara waktu penyelesaian kegiatan ij dikurangi dengan waktu yang dapat dicrash untuk kegiatan ij ditambah dengan saat paling awal kegiatan i. Model matematisnya adalah:

$$
E S_{j}=T_{i j}-D_{i j}+E S_{i} ; \quad j \in J ; \quad i \in I ; \quad i \neq j ; .
$$

Saat paling awal kegiatan $j$ dimulai, jika ada lebih dari satu kegiatan yang mendahului

Untuk kegiatan dengan lebih satu kegiatan yang mendahului, waktu awal kegiatan ditulis sebagai:

$$
E S_{j} \geq T_{i j}-D_{i j}+E S_{i} ; \quad j \in J ; \quad i \in I ; \quad i \neq j ;
$$

Saat paling akhir kegiatan $j$ dapat diselesaikan, jika hanya ada satu kegiatan yang didahului

$\mathrm{LC}_{\mathrm{j}}$ adalah waktu paling akhir penyelesaian kegiatan $\mathrm{j}$, yaitu sama dengan selisih antara waktu penyelesaian kegiatan ij dengan waktu yang dapat dicrash untuk kegiatan ij, ditambah dengan waktu paling akhir penyelesaian kegiatan i. Formulasi dituliskan sebagai:

$$
L C_{j}=T_{i j}-D_{i j}+L C_{i} ; \quad j \in J ; \quad i \in I ; \quad i \neq j ;
$$

Saat paling akhir kegiatan $j$ dapat diselesaikan, jika ada lebih dari satu kegiatan yang didahului

Untuk kegiatan yang mendahului lebih dari satu kegiatan, waktu akhir kegiatan ditulis sebagai:

$$
\mathrm{LC}_{\mathrm{j}} \geqslant \mathrm{T}_{\mathrm{ij}}-\mathrm{D}_{\mathrm{ij}}+\mathrm{LC}_{\mathrm{i}} ; \quad \mathrm{j} \in \mathrm{J} ; \quad \mathrm{i} \in \mathrm{I} ; \quad \mathrm{i} \neq \mathrm{j} ;
$$




\section{Total Float kegiatan}

Total float dari kegiatan ij adalah sama dengan saat paling akhir kegiatan $\mathrm{j}$ dapat diselesaikan dikurangi saat paling awal kegiatan i dapat dimulai, dikurangi waktu penyelesaian kegiatan ij serta ditambah dengan waktu yang dapat dicrash untuk kegiatan ij.

$$
T F_{i j}=L C_{j}-E S_{i}-T_{i j}+D_{i j} ; j \in J ; i-1, \ldots, n ; i \neq j ;
$$

Kegiatan dengan total float sama dengan 0 menunjukkan kegiatan yang berada pada lintasan kritis dalam proyek.

\section{Jumlah waktu yang dapat dicrash yang tersedia untuk masing-masing kegiatan ij}

Jumlah waktu yang dapat dikurangkan untuk masing-masing kegiatan ij. adalah selisih antara waktu penyelesaian proyek normal dan waktu penyelesaian proyek setelah dilakukan pemampatan. Model matematisnya dituliskan sebagai:

$$
D_{i j} \leq \beta_{i j} ; i=1, \ldots, n ; \quad j \in J ; \quad i \neq j ;
$$

\section{HASIL DAN PEMBAHASAN}

Model yang dikembangkan ini selanjutnya diaplikasikan pada proyek perbaikan sebuah kapal. Data yang dibutuhkan sehubungan dengan waktu dan biaya untuk model ini diperoleh dengan melakukan pengamatan dan perkiraan dari supervisor yang menangani perbaikan. Model yang terdiri dari satu fungsi obyektif dengan lebih dari 300 variabel dan 400 kendala ini diselesaikan dengan menggunakan suatu perangkat lunak. Model bisa diselesaikan dalam waktu yang relatif singkat, mengingat bahwa dalam penelitian ini permodelan hanya diterapkan pada suatu bagian kecil dari keseluruhan proyek. Dengan penyelesaian dari model ini diperoleh biaya pemampatan proyek dan kegiatan-kegiatan yang perlu dimampatkan serta waktu pemampatan masing-masing kegiatan.

Secara lebih detail, dari penyelesaian model ini bisa ditentukan kegiatankegiatan mana yang mengalami pemampatan dan mana yang tidak, yang memberi kemungkinan optimal pengaturan sumber daya dan dana. Sesuai dengan tujuan dari optimasi ini, pemampatan akan dilakukan pada kegiatan-kegiatan dengan biaya yang paling rendah, kemudian secara berangsur-angsur akan diterapkan pada kegiatan dengan biaya yang lebih mahal, sehingga tercapai waktu percepatan penyelesaian proyek yang direncanakan. Hasil dari penyelesaian model, sebagai contoh, ditunjukkan pada Tabel 2, yang menunjukkan kegiatan-kegiatan yang bisa dimampatkan, jumlah waktu pemampatan, dan biaya pemampatan.

Dari Tabel 2, tampak bahwa aktifitas-aktifitas yang mengalami crashing process berjumlah 17 aktifitas. Aktifitas 00-01 mempunyai waktu penyelesaian aktifitas selama 1,25 jam, mengalami pemampatan sebesar 0,75 jam sehingga waktu penyclesaian aktifitasnya menjadi 0,5 jam dengan biaya pemampatan sebesar $\mathrm{Rp} \quad 125,25$. biaya pemampatan ini didapat dengan cara mengalikan waktu pemampatan untuk aktifitas 0001 dengan biaya pemampatan untuk aktifitas 00-01 tiap jam pemampatan (terdapat pada Tabel 1). 
Tabel 2. Kegiatan-Kegiatan yang Termampatkan, Jumlah Waktu Pemampatan dan Biaya Pemampatan.

\begin{tabular}{|r|c|c|c|c|r|}
\hline No. & $\begin{array}{c}\text { Activity } \\
\text { Code }\end{array}$ & $\begin{array}{c}\mathbf{T}_{\mathbf{i j}} \text { sebelum } \\
\text { crashing process } \\
\text { (jam) }\end{array}$ & $\begin{array}{c}\mathbf{D}_{\mathbf{i j}} \\
\text { (jam) }\end{array}$ & $\begin{array}{c}\mathbf{T}_{\mathbf{i j}} \text { setelah } \\
\text { crashing process } \\
\text { (jam) }\end{array}$ & $\begin{array}{c}\text { crash cost } \\
\mathbf{R p}\end{array}$ \\
\hline 1 & $00-01$ & 1.25 & 0.75 & 0.5 & 125.25 \\
\hline 2 & $02-03$ & 2 & 1 & 1 & $2,000.00$ \\
\hline 3 & $03-04$ & 2 & 1 & 1 & $4,000.00$ \\
\hline 4 & $08-63$ & 1 & 0.5 & 0.5 & 250.00 \\
\hline 5 & $10-63$ & 1 & 0.5 & 0.5 & 83.50 \\
\hline 6 & $11-63$ & 1 & 0.5 & 0.5 & 83.50 \\
\hline 7 & $12-63$ & 1 & 0.5 & 0.5 & 83.50 \\
\hline 8 & $07-16$ & 4 & 1.5 & 2.5 & $3,250.50$ \\
\hline 9 & $21-22$ & 120 & 28 & 92 & $71,988.00$ \\
\hline 10 & $22-23$ & 4 & 2 & 2 & $1,000.00$ \\
\hline 11 & $07-60$ & 72 & 36 & 36 & $144,000.00$ \\
\hline 12 & $60-61$ & 72 & 5.5 & 66.5 & $22,000.00$ \\
\hline 13 & $63-64$ & 2 & 1 & 1 & $4,000.00$ \\
\hline 14 & $64-65$ & 2 & 1 & 1 & $4,000.00$ \\
\hline 15 & $67-68$ & 0.5 & 0.25 & 0.25 & 500.00 \\
\hline 16 & $68-69$ & 8 & 2 & 6 & $5,000.00$ \\
\hline 17 & $69-71$ & 0.5 & 0.25 & 0.25 & 500.00 \\
\hline
\end{tabular}

\section{KESIMPULAN}

Masalah percepatan penyelesaian proyek dalam kasus ini diaplikasikan pada proyek perbaikan sebuah kapal yang biasanya dikerjakan secara manual, dioptimalkan dengan pembuatan model matematis yang mampu menyelesaikan masalah dengan cara yang lebih efisien, dengan waktu dan biaya yang lebih rendah. Penyelesaian dilakukan dengan mengamati secara simultan semua kegiatan yang bisa dimampatkan dan bisa mengurangi waktu penyelesaian proyek dengan biaya semurah mungkin. Diharapkan dengan permodelan seperti ini, yang bisa dikembangkan lebih jauh untuk memenuhi keinginan perusahaan, bisa ditawarkan kepada pemesan beberapa alternatif waktu penyelesaian proyek dengan konsekuensi kenaikan biaya perbaikan yang bervariasi. Pemesan bisa memilih waktu penyelesaian proyek sesuai dengan keinginan dan dana yang tersedia. Kedua belah pihak, yaitu perusahaan dan pemesan, bisa saling memperoleh kepastian dengan cepat tentang biaya proyek sebagai fungsi waktu.

\section{DAFTAR PUSTAKA}

Santoso, B., 1997. Manajemen Proyek, Edisi pertama, Guna Widya, Jakarta.

Taylor, B. W., 1999. Introduction to Management Science, Prentice Hall International. 
Tubagus, H. A., 1995. Prinsip-Prinsip Network Planning, Cetakan keenam, PT Jakarta Gramedia Pustaka Utama, jakarta.

Ubud, S., 2003. Penjadwalan Multi Proyek Dengan Memperhatikan Keterbatasan Tenaga kerja Di PT Indomarine Malang, Manajemen Industri, Magister Manajemen Teknologi - ITS, tesis yang tidak dipublikasikan, Surabaya. 